\begin{tabular}{|c|c|}
\hline 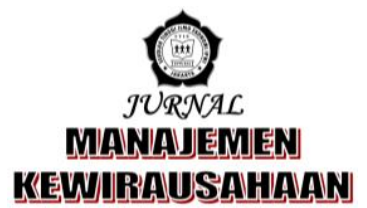 & $\begin{array}{r}\text { p-ISSN 1858-1048 } \\
\text { e-ISSN 2654-9247 } \\
\text { http://ejurnal.stieipwija.ac.id/index.php/imk } \\
\text { DOI: http://dx.doi.org/10.33370/imk.v16i1.304 } \\
\text { Jurnal Manajemen Kewirausahaan Vol. 16 No. 01 - Juni } 2019 \\
\text { Submit: 8 Mei 2019; Review: 17 Jun 2019; Publish: 30 Jun } 2019\end{array}$ \\
\hline
\end{tabular}

\title{
PENGARUH KUALITAS PELAYANAN DAN BRAND IMAGE TERHADAP LOYALITAS NASABAH BANK NEGARA INDONESIA
}

\author{
Oleh: \\ Hafish Sadiq1), Siti Laela ${ }^{2)}$ \\ hafish54sadiq@gmail.com ${ }^{1)}$, siti_laela65@yahoo.com ${ }^{2}$ \\ Sekolah Tinggi Ilmu Ekonomi IPWIJakarta1,2)
}

\begin{abstract}
ABSTRAK
Kualitas pelayanan dan brand image faktor yang diduga relatif besar dalam mempengaruhi loyalitas. Untuk membuktikan pengaruh keduanya maka dilakukan penelitian ini dengan tujuan: 1) Untuk mengetahui pengaruh kualitas pelayanan terhadap loyalitas nasabah; 2) Untuk mengetahui pengaruh brand image terhadap loyalitas nasabah.

Penelitian ini dilakukan di Bank Negara Indonesia KCP DPR RI Senayan Jakarta dengan mengambil nasabah sebagai sampel penelitian yang dihitung menggunakan rumus proporsi untuk populasi besar atau tidak terhingga. Pengambilan data dilakukan dengan instrumen kuesioner tertutup lima skala penilaian dari sangat tidak setuju sampai sangat setuju. Penelitian dilakukan secara kuantitatif yaitu mendeskripsikan data penelitian dan melakukan analisis inferensi. Analisis regresi sederhana dan ganda sebagai analisis sedangkan pengujian hipotesis dilakukan uji $t$ dan uji $F$.

Penelitian menghasilkan dua temuan sesuai dengan hipotesis yang diajukan, yaitu: 1) Kualitas pelayanan berpengaruh signifikan terhadap loyalitas nasabah. Hasil penelitian yang menunjukkan bahwa variabel kualitas pelayanan memiliki tingkat signifikan sebesar $(0,000)<a(0,05) ; 2)$ Brand image berpengaruh signifikan terhadap loyalitas nasabah. Hasil penelitian yang menunjukkan bahwa variabel brand image memiliki tingkat signifikan sebesar $(0,000)<a(0,05)$; 3) Dalam penelitian ini setelah dilakukan pengujian terhadap kedua variabel independen secara simultan ternyata dapat disimpulkan bahwa kualitas pelayanan dan brand image berpengaruh secara simultan terhadap loyalitas nasabah.

Berdasarkan hasil temuan tersebut maka untuk meningkatkan loyalitas nasabah disarankan agar dilakukan upaya memperbaiki kualitas pelayanan dan brand image.
\end{abstract}

Kata Kunci: kualitas pelayanan, brand image, loyalitas nasabah

\section{PENDAHULUAN}

Loyalitas nasabah merupakan keadaan yang diharapkan oleh setiap perbankan. Tingginya loyalitas nasabah, dapat mengindikasikan keberhasilan sebuah perbankan. Loyalitas dapat diartikan kesetiaan, yaitu kesetiaan seseorang terhadap suatu objek
(Maulina, 2015). Secara tidak langsung, loyalitas nasabah dapat meningkatkan daya saing dari sebuah nasabah. Melihat peran loyalitas nasabah sangat krusial bagi perbankan, banyak ahli telah memeriksa kontribusi penting loyalitas nasabah bagi perbankan (He \& Lai, 2014). 
Berbicara mengenai brand image, Suryani (2013:85) mengatakan bahwa brand image sebuah perusahaan mempunyai pengaruh besar dalam mempengaruhi pengambilan keputusan konsumen. Terbentuknya brand image yang baik bagi konsumen mempunyai kesan positif terhadap perusahaan (bank) sehingga secara tidak langsung akan berdampak kepada loyalitas nasabah.

Kottler \& Amstrong (2007) mendefinisikan brand image sebagai seperangkat keyakinan, ide, dan kesan yang dimiliki seorang terhadap suatu merek. Karena itu sikap dan tindakan konsumen terhadap suatu merek sangat ditentukan oleh brand image merupakan syarat dari merek yang kuat. Sedangkan Durianto \& Sugiarto (2004) menyatakan brand image adalah asosiasi brand saling berhubungan dan menimbulkan suatu rangkaian dalam ingatan konsumen. Brand image yang terbentuk di benak konsumen. Konsumen yang terbiasa menggunakan brand tertentu cenderung memiliki konsistensi terhadap brand image.

Permasalahan loyalitas nasabah inilah yang menjadi latar belakang pemikiran mengapa tema ini menarik untuk diteliti. Dipilihnya Bank Negara Indonesia KCP DPR RI Senayan Jakarta sebagai objek penelitian, oleh karena sebagai salah satu lembaga keuangan milik pemerintah, Bank Negara Indonesia KCP DPR RI Senayan Jakarta saat ini tengah menghadapi era persaingan yang sangat kompetitif.

Kemampuan BNI untuk beradaptasi terhadap perubahan dan kemajuan lingkungan, sosial-budaya serta teknologi dicerminkan melalui penyempurnaan identitas perusahaan yang berkelanjutan dari masa ke masa. Hal ini juga menegaskan dedikasi dan komitmen BNI terhadap perbaikan kualitas kinerja secara terus-menerus. Berangkat dari semangat perjuangan yang berakar pada sejarahnya, BNI bertekad untuk memberikan pelayanan yang terbaik bagi negeri, serta senantiasa menjadi kebanggaan negara.

\section{TUJUAN PENELITIAN}

Tujuan dari penelitian ini adalah:

1. Untuk mengetahui pengaruh kualitas pelayanan terhadap loyalitas nasabah Bank Negara Indonesia.

2. Untuk mengetahui pengaruh brand image terhadap loyalitas nasabah Bank Negara Indonesia.

\section{TELAAH LITERATUR DAN PENGEMBANGAN PROPOSISI/HIPOTESIS}

Pendapat lain mengatakan bahwa pemasaran adalah suatu proses sosial dan manejerial dimana individu dan kelompok mendapatkan kebutuhan dan keingian mereka dengan menciptakan, menawarkan, dan bertukar sesuatu yang bernilai satu sama lain. (Daryanto, 2011:1-5).

Pemasaran adalah arahan kegiatan manusia atau kelompok usaha untuk pemuasan keinginan dan pemenuhan kebutuhan lewat satu proses pertukaran adapun pemasaran merupakan sebuah kegiatan usaha yang mengarahkan laju alir barang dan jasa dari produsen kepada konsumen atau siapapun yang memakainya (Nugroho, 2015:42).

Menurut Winardi (2011:6-7), manajemen pemasaran adalah analisis perencanaan, implementasi, dan pengawasan program yang dirancang dengan tujuan untuk menimbulkan pertukaran yang diinginkan dengan pasar yang menjadi tujuan, guna mencapai sasaran organisasi. Jadi, perpaduan fungsi pokok manajemen dan marketing menghasilkan bidang manajemen pemasaran adalah proses pengambilan keputusan, perencanaan, pengawasan aspek-aspek pemasaran sesuatu perusahaan sehubungan dengan konsep pemasaran, di dalam sistem pemasaran.

Selain itu, pihak perbankan juga perlu memperhatikan faktor-faktor yang dapat mempengaruhi loyalitas nasabah. Dalam penelitian ini, akan menganalisa beberapa faktor yang dapat mempengaruhi loyalitas nasabah, yaitu kualitas pelayanan dan brand image yang dimiliki. 


\section{Loyalitas Nasabah \\ Pengertian Loyalitas Nasabah}

Secara umum loyalitas diartikan sebagai pembelian ulang yang terus menerus pada merek yang sama, atau dengan kata lain adalah tindakan seseorang yang membeli merek, perhatian hanya pada merek tertentu, dan tidak mencari informasi yang berkaitan dengan merek tersebut. Menurut Ihryma (2013) kesetiaan (loyalitas) adalah komitmen pelanggan bertahan secara mendalam untuk berlangganan kembali atau melakukan pembelian ulang produk atau jasa terpilih secara konsisten di masa yang akan datang, meskipun pengaruh situasi dan usaha pemasaran mempunyai potensi untuk melakukan perubahan situasi.

Sedangkan menurut Gramer dan Brown (2006) yang dikutip oleh Utomo (2006:27) memberikan definisi mengenai Loyalitas (loyalitas jasa), yaitu derajat sejauh mana seorang konsumen menunjukkan perilaku pembelian berulang dari suatu penyedia jasa, memiliki suatu desposisi atau kecenderungan sikap positif terhadap penyedia jasa, dan hanya mempertimbangkan untuk menggunakan penyedia jasa ini pada saat muncul kebutuhan untuk memakai jasa ini. Dari definisi yang disampaikan Gramer dan Brown (2006), konsumen yang loyal tidak hanya seorang pembeli yang melakukan pembelian berulang, tetapi juga mempertahankan sikap positif terhadap penyedia jasa.

Griffin (2012:5) berpendapat bahwa sesorang pelanggan dikatakan setia atau loyal apabila pelanggan tersebut menunjukkan perilaku pembelian secara teratur atau terdapat sesuatu kondisi dimana mewajibkan pelanggan membeli paling sedikit dua kali dalam selang waktu tertentu. Upaya memberikan kepuasan pelanggan dilakukan untuk mempengaruhi sikap pelanggan, sedangkan konsep loyalitas pelanggan lebih berkaitan dengan perilaku pelanggan daripada sikap dari pelanggan.

Dari definisi di atas dapat disimpulkan bahwa loyalitas nasabah rata-rata ditunjukkannya dengan penggunaan jasa secara berulang karena nasabah merasa puas dengan pelayanan yang diberikan dan dapat disebabkan oleh banyak faktor sehingga terciptalah loyalitas pelanggan.

\section{Faktor-Faktor yang Mempengaruhi Loyalitas Konsumen}

Menurut Riyadi (2009:58) faktorfaktor yang mempengaruhi kesetiaan konsumen sebagai berikut:

1. Kepuasan Satisfaction

2. Perilaku Kebiasaan Habitual Behavior

3. Komitmen Commitment

4. Kesukaan Produk Linking of The Brand

5. Biaya Pengalihan Switching Cost

\section{Dimensi Loyalitas Nasabah}

Pelanggan yang loyal merupakan aset penting perusahaan, hal ini dapat dilihat dari karakteristik yang dimilikinya, sebagaimana diungkapkan Griffin (2012). Pelanggan yang loyal memiliki karakteristik sebagai berikut:

1. Repeat Purchase (kesetiaan terhadap pembelian produk)

2. Retention (ketahanan terhadap pengaruh yang negatif)

3. Referalls (merefensikan secara total esistensi perusahaan)

\section{Kualitas Pelayanan \\ Pengertian Kualitas Pelayanan}

Menurut Wijaya (2011:11), "kua-litas adalah sesuatu yang diputuskan oleh pelanggan, artinya kualitas tersebut didasarkan pada pengalaman aktual konsumen terhadap produk atau jasa yang diukur berdasarkan persyaratan tertentu", sedangkan pelayanan adalah "berbagai aktivitas di seluruh area bisnis yang berusaha mengkombinasikan antara penjualan jasa untuk memenuhi kepuasan konsumen dengan baik" (Ratnasari \& Aksa, 2011:93).

Sementara pelayanan (service) menurut Kotler (2013), yaitu: "A service any act or performance that one party can offer to another that is essentially intangible and does not result in the ownership of anything, its production may or may no be to a physical product". 
Tjiptono (2011:22) mengatakan bahwa, apabila layanan yang diterima atau dirasakan (perceived service) sesuai dengan harapan, maka kualitas pelayanan dipersepsikan baik dan memuaskan, tapi apabila melampaui harapan pelanggan maka menjadi kualitas pelayanan yang ideal. Sebaliknya apabila layanan yang diterima lebih rendah dari yang diharapkan, maka kualitas pelayanan dipersepsikan buruk. Implikasi baik buruknya kualitas suatu layanan tergantung kepada kemampuan penyedia layanan memenuhi harapan pelanggannya secara konsisten

Jadi dapat dikatakan bahwa pengertian kualitas pelayanan dapat dinyatakan sebagai perbandingan antara layanan yang diharapkan konsumen dengan layanan yang diterimanya.

\section{Ciri- Ciri Kualitas Layanan}

Ciri-ciri pelayanan yang baik menurut Hasibuan (2015) yang dikutip oleh Rohmaningtyas (2016) adalah sebagai berikut:

1. Tersedianya sarana dan prasarana yang baik, kelengkapan dan kenyamanan sarana dan prasarana akan mengakibatkan nasabah betah untuk berurutan dengan baik.

2. Tersedianya personil yang baik, kenyamanan nasabah juga sangat bergantung dari petugas CS (Costumer Service) yang melayaninya. Petugas bank harus ramah sopan dan menarik.

3. Bertanggung jawab kepada setiap nasabah dari awal hingga selesai. Nasabah akan merasa puas jika pelayanan yang diberikan sesuai dengan kenyataan.

4. Mampu melayani secara cepat dan tepat, layanan yang diberikan sesuai dengan jadwal atau sesuai dengan keinginan nasabahnya.

Menurut Tjiptono (2011:56) ciri- ciri atau atribut-artribut yang ada dalam kualitas layanan, yaitu:

1. Ketetapan waktu pelayanan yang meliputi waktu tunggu dan waktu proses.

2. Akurasi pelayanan, yang meliputi bebas dari kesalahan-kesalahan.
3. Kesopanan dan keramahan dalam memberikan pelayanan.

4. Kemudahan mendapat pelayanan, misalnya banyaknya petugas yang melayani dan banyaknya fasilitas pendukung seperti komputer.

5. Kenyamanan dalam memperoleh pelayanan, berkaitan dengan lokasi, ruang tempat pelayanan, tempat parkir, kesediaan informasi, dan lainlain.

6. Atribut pendukung pelayanan lainnya seperti ruang tunggu berAC, kebersihan, dan lain-lain.

\section{Dimensi Kualitas Pelayanan}

Parasuraman, et.al. (1988) yang dikutip oleh Sondakh (2014) mengembangkan suatu alat ukur kualitas pelayanan yang dapat digunakan untuk memahami harapan persepsi konsumen terhadap kualitas pelayanan dan membagi kualitas pelayanan dengan sepuluh dimensi sebagai berikut:

1. Fasilitas fisik Tangible atau yang dirasakan yaitu bentuk fisik dari jasa bisa berupa fasilitas fisik, peralatan yang dipergunakan, respresentasi fisik dari jasa (misalnya kartu kredit plastik).

2. Reliabilitas Reliability atau keterandalan mencakup dua hal pokok, yaitu konsistensi kerja (performance) dan kemampuan untuk dipercaya (dependability).

3. Responsivitas Responsiveness atau ketanggapan yaitu kemauan atau kesiapan para karyawan untuk memberikan jasa yang dibutuhkan pelanggan.

4. Kompetensi Competency atau kemampuan artinya setiap orang dalam suatu perusahaan memiliki keterampilan dan pengetahuan yang dibutuhkan agar dapat memberikan jasa tertentu.

5. Tata krama Courtesy atau kesopanan meliputi sikap sopan santun, respek, perhatian, dan keramahan yang dimiliki para contact person (seperti resepsionis, operator telepon, dan lain-lain).

6. Komunikasi Communication artinya memberikan informasi ke dalam 
pelanggan dalam bahasa yang dapat mereka pahami, serta selalu mendengarkan saran dan keluhan konsumen.

7. Kredibilitas Credibility atau sifat jujur dan dapat dipercaya. Kredibilitas mencakup nama perusahaan, reputasi perusahaan, karakteristik pribadi contact personal, dan interaksi dengan pelanggan.

8. Keamanan Security yaitu aman dari bahaya, resiko atau keragu-raguan.

9. Akses Accsess, yaitu kemudahan untuk dihubungi dan ditemui. Hal ini berarti lokasi fasilitas yang mudah dijangkau, waktu menunggu yang tidak lama, saluran komunikasi perusahaan yang mudah dihubungi, dan lain-lain.

10. Perhatian pada pelanggan (Understanding The Customer), yaitu usaha untuk memahami kebutuhan.

\section{Brand image \\ Pengertian Brand Image}

Brand image atau citra merek merupakan representasi dari keseluruhan persepsi terhadap merek dan bentuk dari informasi dan pengalaman masa lalu terhadap merek itu. Menurut Kotler dan Armstrong (2007:301), merek (brand) adalah nama, istilah, tanda, simbol, desain khusus, atau kombinasi dari unsur-unsur tersebut yang berfungsi untuk mengidentifkasi produk perusahaan yang tidak hanya membedakannya dari produk pesaing namun merupakan janji produsen atau kontrak. Kepercayaan dari produsen kepada konsumen dengan menjamin konsistensi bahwa sebuah produk akan selalu dapat menyampaikan nilai yang diharapkan konsumen dari sebuah produk.

Hal senada dijelaskan oleh Shimp (2011:12) bahwa citra merek (brand image) dapat dianggap sebagai jenis asosiasi yang muncul dibenak konsumen ketika mengingat sebuah merek tertentu. Asosiasi tersebut secara sederhana dapat muncul dalam bentuk pemikiran atau citra tertentu yang dikaitkan kepada suatu merek, sama halnya ketika kita berfikir tentang orang lain. Asosiasi ini dapat dikonseptualisasi berdasarkan jenis, dukungan, kekuatan, dan keunikan.

\section{Faktor Sebuah Merek}

Menurut Kotler dan Amstrong (2007:56) bahwa pengukuran citra merek dapat dilakukan berdasarkan pada faktor sebuah merek, yaitu:

1. Kekuatan strength..

2. Keunikan uniquiness.

3. Favourable

Menurut Keller (1993) yang dikutip oleh Rohmaningtyas (2016), faktor-faktor yang membentuk citra merek adalah:

1. Kekuatan asosiasi merek

Menjelaskan bagaimana informasi masuk ke dalam ingatan konsumen dan bagaimana informasi tersebut dapat bertahan sebagai bagian dari brand image.

2. Keuntungan asosiasi merek Kesuksesan sebuah proses pemasaran sering tergantung pada proses terciptanya asosiasi merek yang menguntungkan, dimana konsumen dapat percaya pada produk yang diberikan mereka dapat memuaskan kebutuhan dan keinginan konsumen.

3. Keunikan asosiasi merek Merek harus memiliki keunggulan bersaing yang menjadi alasan bagi konsumen untuk memilih merek tersebut. Keunikan asosiasi merek dapat berdasarkan atribut produk, fungsi produk atau citra yang dinikmati konsumen.

\section{Dimensi Brand image}

Menurut Aaker (2011) bahwa pengukuran brand image dapat dilakukan berdasarkan pada aspek ekuitas merek, yaitu:

1. Kesadaran nama merek brand name awareness.

2. Kesetiaan merek brand loyalty

3. Kesan kualitas perceived quality

4. Asosiasi-asosiasi merek brand associations

Penelitian dilakukan oleh Conny Sondakh (2014), dengan judul "Kualitas Layanan, Citra Merek dan Pengaruhnya terhadap Kepuasan Nasabah dan Loyalitas Nasabah". Populasi dalam penelitian berjumlah 1.157 orang, 
Jumlah sampel 270 orang dengan teknik pengambilan sampel aksidental. Metode pengambilan data dilakukan dengan survei menggunakan kuesioner, dan analisis data menggunakan analisis jalur. Hasil penelitian menunjukkan bahwa variable kualitas pelayanan berpengaruh signifikan terhadap variabel kepuasan nasabah secara parsial. Variabel citra merek berpengaruh tidak signifikan terhadap variabel kepuasan nasabah secara parsial sementara variabel kepuasan nasabah berpengaruh signifikan terhadap variabel loyalitas nasabah.

Penelitian dilakukan oleh Ismayanti Maulina (2015), dengan judul "Pengaruh Kualitas Layanan, Citra Bank dan Kepercayaan terhadap Loyalitas Nasabah Bank BCA di Surabaya". Sampel dalam penelitian ini adalah nasabah Bank BCA di Surabaya yang memenuhi kriteria sebagai responden. Berdasarkan hasil analisis pada uji $t$ didapatkan hasil bahwa kualitas layanan memiliki pengaruh signifikan terhadap loyalitas nasabah dan citra perusahaan memiliki pengaruh signifikan terhadap loyalitas nasabah.

Penelitian dilakukan oleh Agung Johan Wijaya dan Zeplin Jiwa Husada (2016), dengan judul "Analisis Pengaruh Brand Image dan Brand Awareness terhadap Loyalitas Pelanggan melalui Relationship Quality (Studi Kasus pada PT Mikatasa Agung di Surabaya)". Pengambilan sampel dilakukan terhadap responden yang menggunakan lem Rajawali di wilayah Surabaya dan Sidoarjo. Berdasarkan hasil uji hipotesis bahwa brand image, brand awareness, serta relationship quality mempunyai pengaruh yang signifikan terhadap terbentuknya loyalitas pelanggan.

\section{Hubungan Kualitas Pelayanan terhadap Loyalitas Nasabah}

Loyalitas sebagai kondisi dimana nasabah mempunyai sikap positif terhadap suatu jasa perbankan, mempunyai komitmen pada jasa perbankan tersebut dan bermaksud meneruskan penggunaan layanannya di masa mendatang. Nasabah yang loyal sangat berarti bagi perbankan karena biaya untuk mendapatkan nasabah baru lebih mahal daripada memelihara nasabah lebih lama. Untuk meningkatkan loyalitas nasabah dibutuhkan kualitas yang baik, dimana kualitas pelayanan yang baik dalam perbankan dapat mempengaruhi kepuasan nasabah dan berdampak pada meningkatnya loyalitas nasabah. Hal ini didukung penelitian dilakukan oleh Conny Sondakh (2014), Hasil penelitian menunjukkan bahwa variable kualitas pelayanan berpengaruh signifikan terhadap variabel kepuasan nasabah.

Penelitian dilakukan oleh Ismayanti Maulina (2015), dengan judul "Pengaruh Kualitas Layanan, Citra Bank dan Kepercayaan terhadap Loyalitas Nasabah Bank BCA di Surabaya". Oleh karena itu dapat diduga bahwa loyalitas pelayanan berpengaruh positif terhadap loyalitas nasabah.

H1: Kualitas pelayanan berpengaruh positif dan signifikan terhadap loyalitas nasabah Bank Negara Indonesia KCP DPR RI Senayan Jakarta.

\section{Hubungan Brand Image terhadap Loyalitas Nasabah}

Brand image yang baik merupakan salah satu strategi untuk menarik lebih banyak nasabah baru dan berhasil tidaknya suatu merek dalam menarik minat nasabah untuk menggunakan layanan perbankan sangatlah bergantung pada persepsi nasabah terhadap merek tersebut. Perbankan harus mampu menciptakan merek yang menarik dan mampu merepresentasikan jasa layanannya.

Jadi, dapat dikatakan citra yang baik dari suatu merek dapat mengarahkan pada loyalitas nasabah terhadap suatu merek. Hal ini didukung hasil Penelitian dilakukan oleh Agung Johan Wijaya dan Zeplin Jiwa Husada (2016), dengan judul "Analisis Pengaruh Brand Image dan Brand Awareness terhadap Loyalitas Pelanggan melalui Relationship Quality (Studi Kasus pada PT Mikatasa Agung di Surabaya)". Berdasarkan hasil uji hipotesis bahwa brand image, brand awareness, serta relationship quality mempunyai pengaruh yang signifikan terhadap terbentuknya loyalitas 
pelanggan. Oleh karena itu dapat diduga bahwa Brand Image berpengaruh positif dan signifikan terhadap loyalitas nasabah

$\mathrm{H} 2$ : Brand image berpengaruh positif dan signifikan terhadap loyalitas nasabah Bank Negara Indonesia KCP DPR RI Senayan Jakarta.

\section{Gambar 1}

Kerangka/Konstelasi

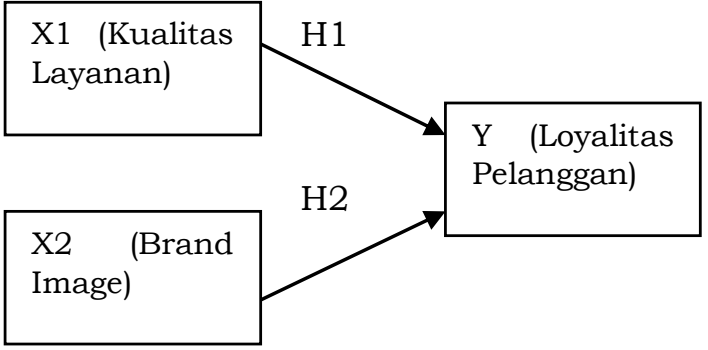

\section{METODE PENELITIAN}

Penelitian ini dilakukan dengan pendekat kuantitatif dan jenis penelitian yang digunakan adalah penelitian eksplanatory yang bersifat asosiatif, merupakan penelitian yang bertujuan mengetahui hubungan antara dua variabel atau lebih (Sugiyono, 2014). Pada penelitian ini, yang menjadi subyek penelitian adalah nasabah Bank Negara Indonesia KCP DPR RI Senayan Jakarta.

\section{Sampel Penelitian}

Teknik pengambilan sampel adalah purposive sampling yaitu pengambilan sample berdasarkan kriteria responden :

1. Nasabah Bank Negara Indonesia KCP DPR RI Senayan Jakarta dan telah menjadi nasabah selama \pm 5 tahun.

2. Penarikan sampel dan kuesioner langsung ditujukan kepada nasabah Bank Negara Indonesia KCP DPR RI Senayan Jakarta sebanyak 150 orang.

\section{Desain Penelitian}

Variabel yang digunakan dalam penenlitian ini adalah:

1. Variabel bebas (independen) yaitu variabel yang dapat mempengaruhi variabel terikat. Adapun yang merupakan variable bebas yang digunakan dalam penelitian ini adalah:

1) Kualitas Pelayanan (X1)

Kualitas pelayanan dapat dinyatakan sebagai perbandingan antara layanan yang diharapkan konsumen dengan layanan yang diterimanya. Indikator yang digunakan dalam variabel kualitas pelayanan (X1)

2) Brand image (X2)

Brand image merupakan serangkaian kepercayaan konsumen tentang merek tertentu sehingga asosiasi merek tersebut melekat di benak konsumen. Secara keseluruhan, indikator yang digunakan dalam variabel brand image (X2).

2. Variabel terikat yaitu faktor yang diobservasi dan diukur untuk menentukan adanya pengaruh variabel bebas. Dalam penelitian ini variabel terikatnya adalah loyalitas pelanggan.

\section{Operasionalisasi Variabel}

Operasionalisasi variabel penelitian dapat dikemukakan sebagai berikut: Tabel 1

Variabel Kualitas Pelayanan (X1)

\begin{tabular}{|c|c|c|}
\hline Dimensi & Indikator & $\begin{array}{c}\text { No } \\
\text { Pertanyaan }\end{array}$ \\
\hline Tangibles & $\begin{array}{ll}\text { 1. } & \text { Fasilitas } \\
\text { penunjang } \\
\text { 2. }\end{array}$ & $1-2$ \\
\hline Reliability & $\begin{array}{ll}\text { 3. } & \text { Proses } \\
\text { pelayanan } \\
\text { 4. } \\
\text { Penanganan } \\
\text { masalah }\end{array}$ & $3-4$ \\
\hline Responsiveness & $\begin{array}{ll}\text { 5. Ketanggapan } \\
\text { petugas } \\
\text { 6. Petugas } \\
\text { keamanan }\end{array}$ & $5-6$ \\
\hline Assurance & $\begin{array}{ll}\text { 7. } & \begin{array}{l}\text { Kesopanan } \\
\text { dalam }\end{array} \\
\text { penampilan } \\
\text { 8. }\end{array}$ & $7-8$ \\
\hline Emphaty & $\begin{array}{l}\text { 9. Perhatian yang } \\
\text { diberikan } \\
\text { petugas } \\
\text { 10. Waktu } \\
\text { operasional } \\
\text { bank }\end{array}$ & $9-10$ \\
\hline
\end{tabular}

Sumber: Parasuraman, et.al. (1988), dalam Arief (2007) 
Tabel 2

Variabel Brand Image (X2)

\begin{tabular}{|c|c|c|}
\hline Dimensi & Indikator & $\begin{array}{c}\text { No } \\
\text { Pertanyaan }\end{array}$ \\
\hline $\begin{array}{l}\text { Brand Name } \\
\text { Awareness }\end{array}$ & $\begin{array}{l}\text { 1. Pengenalan merek } \\
\text { 2. Menyadari } \\
\text { adanya merek } \\
\text { 3. Yang pertama kali } \\
\text { disebutkan }\end{array}$ & $1-3$ \\
\hline $\begin{array}{l}\text { Brand } \\
\text { Loyalty }\end{array}$ & $\begin{array}{l}\text { 4. Pengetahuan logo } \\
\text { 5. Kesesuaian harga } \\
\text { 6. Lokasi strategis }\end{array}$ & $4-6$ \\
\hline $\begin{array}{l}\text { Perceived } \\
\text { Quality }\end{array}$ & $\begin{array}{l}\text { 7. Jasa pelayanan } \\
\text { bank yang baik } \\
\text { 8. Jasa pelayanan } \\
\text { yang berkualitas }\end{array}$ & $7-8$ \\
\hline $\begin{array}{l}\text { Brand } \\
\text { Associations }\end{array}$ & $\begin{array}{l}\text { 9. Kepuasaan } \\
\text { terhadap merek } \\
\text { 10. Kebanggaan } \\
\text { terhadap merek }\end{array}$ & $9-10$ \\
\hline
\end{tabular}

Sumber: Aaker (2011)

Tabel 3

Variabel Loyalitas Pelanggan (Y)

\begin{tabular}{|c|c|c|}
\hline Dimensi & Indikator & $\begin{array}{c}\text { No } \\
\text { Pertanyaan }\end{array}$ \\
\hline $\begin{array}{l}\text { Repeat } \\
\text { Purchase }\end{array}$ & $\begin{array}{l}\text { 1. Pembelian rutin } \\
\text { 2. Program promosi } \\
\text { 3. Kualitas produk }\end{array}$ & $1-3$ \\
\hline Retention & $\begin{array}{l}\text { 4. Pilihan utama } \\
\text { 5. Tidak memiliki } \\
\text { keinginan untuk } \\
\text { berpindah } \\
\text { 6. Tawaran yang } \\
\text { beragam }\end{array}$ & $4-6$ \\
\hline Referalls & $\begin{array}{l}\text { 7. Merekomendasikan } \\
\text { 8. Menceritakan hal } \\
\text { baik } \\
\text { 9. Mengajak orang lain }\end{array}$ & $7-9$ \\
\hline
\end{tabular}

Sumber: Griffin (2012)

\section{Metode Analisis}

Analisis data menggunakan software SPSS dengan empat tahap. Pertama, pengujian kualitas data. Tahap kedua, melakukan uji penyimpangan asumsi klasik. Tahap ketiga, melakukan analisis regresi berganda. Dan tahap keempat, melakukan pengujian hipotesis.

\section{Uji Validitas}

Sebuah instrumen dikatakan valid apabila instrumen itu mampu mengukur apa yang diinginkan dan dapat mengukur data dari variabel yang diteliti secara tepat.

\section{Uji Reliabilitas}

Reliabilitas menunjukkan pada suatu pengertian bahwa suatu instrumen cukup dapat dipercaya untuk digunakan sebagai alat pengumpul data karena instrumen tersebut sudah baik (Arikunto, 2012:154).

Instrumen yang sudah dapat dipercaya, yang reliabel akan menghasilkan data yang dapat dipercaya juga.

\section{Uji Asumsi Klasik}

Uji normalitas digunakan untuk memastikan bahwa data yang digunakan untuk analisis berasal dari data variabel yang berdistribusi normal. Uji normalitas dalam penelitian ini dilakukan untuk menguji normalitas data dari masingmasing variabel dengan menggunakan one-sample kolmogorov-smirnov.

\section{Analisis Korelasi Berganda}

Analisis ini digunakan untuk mengetahui pola kekuatan dari pengaruh variabel bebas terhadap variabel terikat. Guna mengetahui lebih lanjut besarnya "pengaruh kualitas pelayanan dan brand image terhadap loyalitas nasabah Bank Negara Indonesia KCP DPR RI Senayan Jakarta" maka perlu diketahui nilai koefisien Korelasi Berganda nilai (R).

Koefisien determinasi (R2) pada intinya mengukur seberapa jauh Pembinaan model dalam menerangkan variasi variabel dependen. Nilai koefisien determinasi adalah antara nol dan satu. Nilai R2 yang kecil berarti pembinaan variabel-variabel independen dalam menjelaskan variasi variabel dependen amat terbatas.

\section{Analisis Regresi Berganda}

Analisis ini digunakan untuk menunjukkan pengaruh variabel bebas terhadap variabel terikat.

\section{HASIL DAN PEMBAHASAN Uji Validitas dan Uji Reabilitas}

Hasil uji validitas dan realibilitas masing-masing variabel adalah:

\section{Uji Validitas dan Reabilitas Kualitas Pelayanan (X1)}

Berdasarkan hasil perhitungan uji validitas variabel kualitas pelayanan (X1) dengan 10 item pertanyaan, maka didapat hasil seluruh pertanyaan untuk variabel kualitas pelayanan (X1) memiliki status valid, karena nilai $r$ hitung 
(Corrected Item-Total Correlation) $>\mathrm{r}$ tabel sebesar 0,279.

Sedangkan hasil uji reabilitas menunjukkan bahwa nilai cronbach's alpha atas variabel kualitas pelayanan (X1) sebesar 0,916. Sehingga dapat disimpulkan bahwa pertanyaan dalam kuesioner tersebut reliable, karena mempunyai nilai cronbach's alpha lebih besar dari 0,60

\section{Uji Validitas dan Reabilitas Brand Image (X2)}

Berdasarkan hasil perhitungan uji validitas variabel brand image (X2) dengan 10 item pertanyaan maka hasil uji seluruh pertanyaan untuk variabel brand image (X2) memiliki status valid, karena nilai $\mathrm{r}$ hitung (Corrected ItemTotal Correlation) > $r$ tabel sebesar 0,279.

Berdasarkan hasil uji reabilitas menunjukkan bahwa nilai cronbach's alpha atas variabel brand image (X2) sebesar 0,922. Sehingga dapat disimpulkan bahwa pertanyaan dalam kuesioner tersebut reliable, karena mempunyai nilai cronbach's alpha lebih besar dari 0,60

\section{Uji Validitas dan Reabilitas Loyalitas Nasabah (Y)}

Berdasarkan hasil perhitungan uji validitas variabel loyalitas nasabah $(\mathrm{Y})$ dengan 10 item pertanyaan uji validitas, seluruh pertanyaan memiliki status valid, karena nilai $\mathrm{r}$ hitung (Corrected Item-Total Correlation) $>\mathrm{r}$ tabel sebesar 0,279 .

Dari hasil uji reabilitas menunjukkan bahwa nilai cronbach's alpha atas variabel loyalitas nasabah (Y) sebesar 0,935. Sehingga dapat disimpulkan bahwa pertanyaan dalam kuesioner tersebut reliable, karena mempunyai nilai cronbach's alpha lebih besar dari 0,60.

\section{Uji Asumsi Klasik}

Berdasarkan output uji asumsi diketahui bahwa nilai signifikansi untuk kualitas pelayanan sebesar 0,308 , brand image sebesar 0,400 dan loyalitas nasabah sebesar 0,376 lebih besar dari 0,05, sehingga dapat disimpulkan bahwa data yang diuji berdistribusi normal.
Analisis Korelasi Berganda

Tabel 4

Korelasi Berganda

\begin{tabular}{|l|l|r|r|r|}
\hline \multicolumn{2}{|c|}{} & \multicolumn{1}{c|}{$\begin{array}{c}\text { Loyalitas } \\
\text { Nasabah (Y) }\end{array}$} & $\begin{array}{c}\text { Kualitas } \\
\text { Pelayanan (X1) }\end{array}$ & $\begin{array}{c}\text { Brand Image } \\
(\mathrm{X} 2)\end{array}$ \\
\hline Pearson Correlation & Loyalitas Nasabah (Y) & 1.000 & 0.623 & 0.561 \\
\cline { 2 - 5 } & $\begin{array}{l}\text { Kualitas Pelayanan } \\
(\mathrm{X} 1)\end{array}$ & 0.623 & 1.000 & 0.420 \\
\cline { 2 - 5 } & Brand image (X2) & 0.561 & 0.420 & 1.000 \\
\hline \multirow{3}{*}{ Sig. (1-tailed) } & Loyalitas Nasabah (Y) & & 0.000 & 0.000 \\
\cline { 2 - 5 } & $\begin{array}{l}\text { Kualitas Pelayanan } \\
\text { (X1) }\end{array}$ & 0.000 & & 0.000 \\
\cline { 2 - 5 } & Brand image (X2) & 0.000 & 0.000 & \\
\hline N & Loyalitas Nasabah (Y) & 150 & 150 & 150 \\
\cline { 2 - 6 } & Kualitas Pelayanan & 150 & 150 & 150 \\
\cline { 2 - 5 } & Brand image (X2) & 150 & 150 & 150 \\
\hline
\end{tabular}

Dari analisis korelasi berganda diperoleh nilai koefisien korelasi untuk kualitas pelayanan (X1) sebesar 0,623 dan brand image (X2) sebesar 0,561 dengan signifikansi 0,000 . Dalam hal ini dapat dilihat bahwa koefisien korelasi adalah 0,623 dan 0,561 dengan signifikansi 0,000. Karena signifikansi < 0,05 maka Ha diterima yang artinya terdapat hubungan antara kualitas pelayanan (X1) dan brand image (X2) dengan loyalitas nasabah (Y) di Bank Negara Indonesia KCP DPR RI Senayan Jakarta. Hubungan kedua variabel tersebut berbanding lurus, yakni semakin positif kualitas pelayanan (X1) dan brand image (X2) maka akan diikuti semakin tingginya loyalitas nasabah $(\mathrm{Y})$. Begitupun sebaliknya, semakin negatif kualitas pelayanan (X1) dan brand image (X2) maka akan diikuti semakin rendahnya loyalitas nasabah $(\mathrm{Y})$.

\section{Koefisien Determinasi}

Tabel 5

Koefisien Determinasi

\begin{tabular}{|l|c|r|r|r|}
\hline Model & R & R Square & \multicolumn{1}{|c|}{$\begin{array}{c}\text { Adjusted R } \\
\text { Square }\end{array}$} & $\begin{array}{c}\text { Std. Error of } \\
\text { the Estimate }\end{array}$ \\
\hline 1 & $.705^{\mathrm{a}}$ & 0.497 & 0.490 & 2.696 \\
\hline \multicolumn{2}{|l|}{} \\
a. Predictors: (Constant), Brand image (X2), Kualitas Pelay anan (X1)
\end{tabular}

Dari tabel di atas diketahui besarnya kontribusi variabel kualitas pelayanan (X1) dan brand image (X2) terhadap loyalitas nasabah (Y) di Bank Negara Indonesia KCP DPR RI Senayan Jakarta dengan melihat hasil Adjusted R Square atau (Adjusted R2) = 0,490. Hal ini berarti bahwa variabel kualitas pelayanan (X1) dan brand image (X2) menjelaskan perubahan pada variabel loyalitas nasabah (Y) sebesar 49\% sedangkan sisanya yaitu $51 \%$ dijelaskan oleh faktorfaktor lain di luar model. 
Analisis Regresi Berganda

Tabel 6

Coefficients

\begin{tabular}{|c|c|c|c|c|c|c|}
\hline \multirow[b]{2}{*}{ Model } & & \multicolumn{2}{|c|}{$\begin{array}{c}\text { Unstandardized } \\
\text { Coefficients }\end{array}$} & \multirow{2}{*}{$\begin{array}{c}\begin{array}{c}\text { Standardized } \\
\text { Coefficients }\end{array} \\
\text { Beta } \\
\end{array}$} & \multirow[b]{2}{*}{$\mathrm{t}$} & \multirow[b]{2}{*}{ Sig. } \\
\hline & & B & Std. Error & & & \\
\hline \multirow[t]{3}{*}{1} & (Constant) & 15.986 & 2.178 & & 7.339 & 0.000 \\
\hline & Kualitas Pelayanan $(\mathrm{X} 1)$ & 0.396 & 0.054 & 0.471 & 7.307 & 0.000 \\
\hline & Brand image (X2) & 0.242 & 0.043 & 0.363 & 5.627 & 0.000 \\
\hline
\end{tabular}

Sumber: data primer yang diolah, 2018

Dari persamaan regresi tersebut dapat diinterprestasikan berikut:

$\hat{\mathrm{Y}}=15,986+0,396 \mathrm{X} 1+0,242 \mathrm{X} 2+\mathrm{e}$

1. Nilai konstanta regresi sebesar 15,986, menunjukkan bahwa pada kualitas pelayanan (X1) dan brand image (X2) dengan kondisi konstan atau $\mathrm{X}=0$, maka loyalitas nasabah (Y) pada Bank Negara Indonesia KCP DPR RI Senayan Jakarta sebesar 15,986 .

2. Kualitas pelayanan (X1) koefisien regresinya sebesar 0,396, mempunyai pengaruh positif terhadap loyalitas nasabah (Y). Artinya apabila kualitas pelayanan (X1) semakin baik dengan asumsi variabel lain konstan, maka hal tersebut dapat meningkatkan loyalitas nasabah (Y) pada Bank Negara Indonesia KCP DPR RI Senayan Jakarta sebesar 0,396.

3. Brand image (X2) koefisien regresinya sebesar 0,242, mempunyai pengaruh yang positif terhadap loyalitas nasabah (Y). Artinya apabila brand image (X2) semakin tinggi dengan asumsi variabel lain konstan, maka hal tersebut dapat meningkatkan loyalitas nasabah (Y) pada Bank Negara Indonesia KCP DPR RI Senayan Jakarta sebesar 0,242.

Dari hasil koefisien regresi terlihat bahwa kualitas pelayanan (X1) mempunyai pengaruh lebih tinggi dibandingkan brand image (X2) terhadap loyalitas nasabah (Y) di Bank Negara Indonesia KCP DPR RI Senayan Jakarta, yang didasarkan pada nilai koefisien regresi sebesar 0,396 (unstadardized coeficients) dan nilai Beta sebesar 0,471 (standardized coefficients) dengan signifikan sebesar 0,000 atau sig. sebesar 0\%.

\section{Hasil Uji Kelayakan Model (Uji Statistik} F)

Hasil uji $\mathrm{F}$ menunjukan bahwa $\mathrm{F}$ hitung diperoleh sebesar 72,617 dengan tingkat probabilitas 0,000. Hal ini membuktikan bahwa kualitas pelayanan (X1) dan brand image (X2) berpengaruh secara simultan terhadap loyalitas nasabah (Y). Hal ini dikarenakan tingkat probabilitas jauh lebih kecil dari 0,05.

\section{Uji Signifikansi Parameter Individual (Uji Statistik t)}

Berdasarkan hasil analisis regresi antara kualitas pelayanan (X1) dan brand image (X2) terhadap loyalitas nasabah (Y) di Bank Negara Indonesia KCP DPR RI Senayan Jakarta, maka dapat diuraikan sebagai berikut:

1. Uji signifikan kualitas pelayanan (X1) terhadap loyalitas nasabah $(\mathrm{Y})$

Dalam uji signifikan antara kualitas pelayanan (X1) terhadap loyalitas nasabah $(\mathrm{Y})$, diperoleh nilai t hitung $=7,307$ dan sig $\mathrm{t}$ hitung $=0,000<$ 0,05 . Dengan demikian pengaruh kualitas pelayanan dengan loyalitas nasabah dapat dikatakan mempunyai pengaruh yang signifikan.

2. Uji signifikan brand image (X2) terhadap loyalitas nasabah (Y) Uji signifikan antara variabel brand image (X2) terhadap loyalitas nasabah (Y), maka diperoleh t hitung $=5,627$ dan sig $\mathrm{t}$ hitung $=0,0000<$ 0,05 . Hal ini membuktikan terdapat pengaruh yang signifikan antara variabel brand image (X2) terhadap loyalitas nasabah $(\mathrm{Y})$.

\section{Pembahasan}

\section{Pengaruh Kualitas Pelayanan terhadap Loyalitas Nasabah di Bank Negara Indonesia KCP DPR RI Senayan Jakarta}

Hasil hipotesis menunjukkan bahwa kualitas pelayanan (X1) berpengaruh signifikan terhadap loyalitas nasabah $(\mathrm{Y})$. Jadi semakin baik kualitas pelayanan yang diberikan karyawan Bank Negara Indonesia KCP DPR RI Senayan Jakarta maka semakin besar pengaruh terhadap loyalitas nasabah yang dihasilkan. Penelitian ini konsisten dengan 
penelitian yang dilakukan oleh Conny Sondakh (2014) dan Ismayanti Maulina (2015) bahwa terdapat pengaruh kualitas pelayanan terhadap loyalitas nasabah.

\section{Pengaruh Brand Image terhadap Loyalitas Nasabah di Bank Negara Indonesia KCP DPR RI Senayan Jakarta.}

Hasil hipotesis menunjukkan bahwa brand image (X2) berpengaruh signifikan terhadap loyalitas nasabah (Y). Jadi semakin baik brand image yang dimiliki Bank Negara Indonesia KCP DPR RI Senayan Jakarta maka semakin besar pengaruh terhadap loyalitas nasabah. Hasil penelitian ini sesuai dengan penelitian yang dilakukan oleh Conny Sondakh (2014), Ismayanti Maulina (2015) dan Agung Johan Wijaya dan Zeplin Jiwa Husada (2016) bahwa terdapat pengaruh brand image terhadap loyalitas nasabah.

\section{KESIMPULAN}

\section{Simpulan}

1. Kualitas pelayanan berpengaruh signifikan terhadap loyalitas nasabah. Artinya semakin meningkat kualitas pelayanan maka akan meningkatkan loyalitas nasabah.

2. Brand image berpengaruh signifikan terhadap loyalitas nasabah. Artinya semakin baik brand image maka akan meningkatkan loyalitas nasabah.

\section{Saran}

1. Dari hasil penelitian ini kulalitas pelayanan terhadap loyalitas nasabah yang sudah baik seharusnya dipertahankan dan juga dapat meningkatkan fasilitas ruang tunggu dengan menyediakan bahan bacaan seperti majalah dan surat kabar untuk para nasabah dan layanan internet Wifi serta saluran listrik untuk charger telepon genggam.

2. Dari hasil penelitian terhadap brand image terhadap loyalitas nasabah sudah positif. Harus dipertahankan dan bisa ditambah membuat forum khusus nasabah yang dapat digunakan untuk membagi informasi mengenai keadaan perusahaan

\section{DAFTAR PUSTAKA}

Arief, M. (2007). Pemasaran Jasa dan Kualitas Pelayanan. Malang: Bayumedia Publishing.

Arikunto, S. (2012). Prosedur Penelitian, Suatu Pendekatan Praktek. Jakarta: PT. Rineka Cipta.

Daryanto. (2011). Sari Kuliah Manajemen Pemasaran. Bandung: PT Sarana Tutorial Nurani Sejahtera.

Durianto, D., \& L. J. Sugiarto. (2004). Brand Equity Ten Strategi Memimpin Pasar. Jakarta: PT Gramedia Pustaka Utama.

Gramer, \& Brown. (2006). Loyalitas Pelanggan sebagai Strategi Bersaing. Jakarta: Erlangga.

Griffin, J. (2012). Customer Loyalty How to Earn It, How to Keep It. Kentucky: McGraw-Hill.

Hasibuan, M. SP. (2015). Manajemen Sumber Daya Manusia. Jakarta: Penerbit Bumi Aksara.

He, Y., \&K. K. Lai. (2014). The Effect Of Corporate Social Responsibility On Brand Loyalty: The Mediating Role Of Brand Image. Total Quality Management, 25(3), 249-263.

Ihryma, L. N. (2013). Analisis Loyalitas Nasabah Pembiayaan dan Pendapataan BMT Hubbul Wathon Sumowono. TugasAkhir D3 PerbankanSyariah. STAIN Salatiga.

Keller, L. (1993). How to Manage Brand Equity. Jakarta: Gramedia Pustaka Utama.

Kotler, P. (2013). Manajemen Pemasaran (11ed). Jakarta: Indeks Kelompok Gramedia.

Kotler, P., \& G. Armstrong. (2007). Dasardasar Pemasaran(9ed. Jilid 1). Jakarta: PT. Indeks.

Maulina, I. (2015). Pengaruh Kualitas Layanan, Citra Bank dan Kepercayaan terhadap Loyalitas Nasabah Bank BCAdi Surabaya. Artikel Ilmiah. Sekolah Tinggi Ilmu Ekonomi Perbanas Surabaya.

Nugroho, A. (2015). Tata Terampil Manajemen. Surabaya: INDAH Surabaya. 
Parasuraman, A., V. A. Zeithaml, \&L. L. Berry. (1988). SERVQUAL: A Multiple-Item Scale for Measuring Consumer Perceptions of Service Quality. Journal of Retailing, 64(1), 12-37.

Ratnasari, R. T., \&M. H. Aksa. (2011). Manajemen Pemasaran Jasa. Bogor: Ghalia Indonesia.

Riyadi, J. (2009). Gerbang Pemasaran. Jakarta: Gramedia.

Rohmaningtyas, M. N. (2016). Pengaruh Brand Image, Kualitas Pelayanan dan Kepuasan Nasabah terhadap Loyalitas Nasabahdi Lembaga Keuangan Mikro Syariah. Skripsi. Institut Agama Islam Negeri (IAIN), Salatiga.

Shimp, T. A. (2011). Periklanan Promisi Aspek Tambahan Komunikasi Pemasaran Terpadu. Jakarta: Erlangga.

Sondakh, C. (2014). Kualitas Layanan, Citra Merek dan Pengaruhnya terhadap Kepuasan Nasabah dan Loyalitas Nasabah Tabungan (Studi pada Nasabah Taplus BNI Cabang Manado). Jurnal Riset Bisnis dan Manajemen, 3(1), 19-32.
Sugiyono. (2014). Metode Penelitian Manajemen. Bandung: Alfabeta.

Suryani, T. (2013). Perilaku Konsumen di Era Internet. Yogyakarta: Graha Ilmu.

Tjiptono, F. (2011). Kualitas Jasa: Pengukuran, Keterbatasan dan Implikasi Manajerial. Jakarta: Majalah Manajemen Usahawan Indonesia.

Utomo, P. D. (2006). Analisis Terhadap Faktor-Faktor Yang Mempengaruhi Loyalitas Konsumen Pada Operator Telepon Seluler. Thesis. Universitas Gadjah Mada.

Wijaya, A. J., \&Z. J. Husada. (2016). Analisis Pengaruh Brand Image dan Brand Awareness terhadap Loyalitas Pelanggan melalui Relationship Quality (Studi Kasus pada PT Mikatasa Agung di Surabaya). Program Studi MMTITS, Surabaya.

Wijaya, T. (2011). Manajemen Kualitas Jasa. Jakarta: PT INDEKS.

Winardi. (2011). Marketing dan Perilaku Konsumen. Bandung: Mandar Maju. 